\title{
人工知能を用いた薬物副作用としての痙攣誘発活性の予測
}

\author{
高 夢 璇, ${ }^{a}$ 佐 藤 元 重, ${ }^{a}$ 池 谷 裕二*,a,b
}

\section{Machine Learning-based Prediction of Seizure-inducing Action as an Adverse Drug Effect}

\author{
Mengxuan Gao, ${ }^{a}$ Motoshige Sato,${ }^{a}$ and Yuji Ikegaya ${ }^{*, a, b}$ \\ ${ }^{a}$ Graduate School of Pharmaceutical Sciences, The University of Tokyo; 7-3-1 Hongo, Bunkyo-ku, Tokyo 113-0033, \\ Japan: and ${ }^{b}$ Center for Information and Neural Networks; 1-4 Yamadaoka, Suita, Osaka 565-0871, Japan.
}

(Received October 11, 2017)

\begin{abstract}
During the preclinical research period of drug development, animal testing is widely used to help screen out a drug's dangerous side effects. However, it remains difficult to predict side effects within the central nervous system. Here, we introduce a machine learning-based in vitro system designed to detect seizure-inducing side effects before clinical trial. We recorded local field potentials from the CA1 alveus in acute mouse neocortico-hippocampal slices that were bath-perfused with each of 14 different drugs, and at 5 different concentrations of each drug. For each of these experimental conditions, we collected seizure-like neuronal activity and merged their waveforms as one graphic image, which was further converted into a feature vector using Caffe, an open framework for deep learning. In the space of the first two principal components, the support vector machine completely separated the vectors (i.e., doses of individual drugs) that induced seizure-like events, and identified diphenhydramine, enoxacin, strychnine and theophylline as "seizure-inducing" drugs, which have indeed been reported to induce seizures in clinical situations. Thus, this artificial intelligence-based classification may provide a new platform to pre-clinically detect seizure-inducing side effects of drugs.
\end{abstract}

Key words_ — artificial intelligence; side effect; epilepsy; clinical; toxicity

\section{はじめに}

2016 年 3 月，世界中を駆け巡ったニュースは記 憶に新しく，誰もが衝撃を受けたことだろう。人工 知能 AlphaGo が世界最強のプロ囲碁棋士，李世歪 9 段（国際棋戦で 18 回の優勝経験あり）を見事に 下した。長年の人類 $v s$. 人工知能 (artificial intelligence；AI）というボードゲームにおける勝負の中 で人類にとっては最後の砦であった囲碁で, ついに,

$\mathrm{AI}$ が人類を凌駕した瞬間である。近い将来は不可 能と言われてきた中でのこの勝利は，AI 技術が予 想を上回る加速度的進歩を遂げていることを裏付け るものとなった.

AI は医療界にも進出している。特に畳み込み ニューラルネットワークを用いた「ディープラーニ

$a$ 東京大学大学院薬学系研究科（T113-0033 東京都文 京区本郷 7-3-1), ${ }^{b}$ 脳情報通信融合研究センター （CiNet）（广565-0871 大阪府吹田市山田丘 1-4）

*e-mail: yuji@ikegaya.jp

本総説は, 日本薬学会第 137 年会シンポジウムS15 で

発表した内容を中心に記述したものである.
ング」の医療画像分析に関する論文は 2015 年以降 急増した。 ${ }^{1)}$ 病態の分類や腫瘍の検出などの正確性 (Accuracy) において 90\%を超える報告も多い. Guan et al. では，ニューラルネットワーク「selfvalidation cerebellar model articulation controller; SVCMAC」を用いて, 乳がんの診断における腫瘍 の良性・悪性を分類している. ${ }^{2}$ 従来の型のニュー ラルネットワークに自己検証（self validation）の 機能を追加しているのが特徵で, 683 の乳がんデー 夕を $50 \%$ 学習用に，30\%を validation 用に，20\% をテスト用に用いたところ Accuracy で 96.5\%を実 現した。 また，ニューラルネットワーク以外の例と してファジー論理を用いた人工知能も活躍をみせて いる. Shankar et al. ではグレーレベル同時生起行 列 (gray level coocurrence matrix; GLCM) による 空間フィルタ処理により脳の MRI 画像から特徵量 を抽出し, Gustafson-Kessel Fuzzy 分類アルゴリズ ムにより正常か異常かを判別させたところ, 全デー タセットで $95 \%$ を超える Accuracy となつた. ${ }^{3)}$ ま た，私たちの本研究では，ニューラルネットワーク 
Caffe を用いた手法で薬剤の瘥攣誘発性副作用の検 出に検討薬物は少量ながら $100 \%$ の Accuracy を達 成した.

ヒトにおいて瘥攣を誘発する副作用が報告されて いる薬物は，解熱鎮痛剤や抗生物質を始めとして様 々知られている，当然，医薬品が出回る前にあらか じめこの副作用の存在を検出することは肝要であ る. その検出法として，この種の薬物の投与により 海馬急性スライスに特徵的な局所場電位（local field potential; LFP) の変化が引き起こされること が知られている。しかし，この変化は視認は容易だ が，電位の変動を古典的な数学により定義し，統計 学的に判別することが困難であった.

そこで，電位の変動に着目するのではなく，人間 の視認による判断に着想を得て LFP を画像として 扱い，AI に画像認識させることにした。 マウスの 海馬急性スライスにおいて，薬物適用時に記録され た LFP から神経活動をすべて検出して画像に変換 し，画像をニューラルネットワーク Caffe に識別さ せることで，瘥攣誘発性の有無を判定させた，結果 は，Accuracy で $100 \%$ となり，AI の威力を存分に 思い知らされる結果となった。

この研究成果は医薬品開発の前臨床試験における 新たな評価方法になると期待される。現在まで，前 臨床試験において中枢神経系に対する副作用の検出 は困難とされているが, ${ }^{4)} \mathrm{AI}$ を用いた前臨床試験が 実現できれば，人間の目による判断に伴うバイアス や疲れを排除でき，明瞭な基準による正確な振り分 けが可能となるはずである，以下に詳細に記述する.

\section{海馬急性スライスにおける病攣様発火の観察}

病攣誘発作用を持つ薬物は，海馬急性スライスに おいて同期かつ持続的な異常発火を引き起こすこと が知られている。5)こうした発火は痤攣様発火 (seizure-like event; SLE) と呼称され，LFP の記録 により検出できる。私たちは SLE の発生を確認す るために，まず $\gamma$-アミノ酪酸（gamma-aminobutyric acid; GABA) 拮抗薬であるピクロトキシンをマ ウスの海馬急性スライスに適用した。また，神経細 胞の興奮性を高め, SLE の発生を促進するため に，スライスを還流する人工脳脊髄液中の $\mathrm{Mg}^{2+}$ 濃 度をあらかじめ低下させた. ${ }^{6}$

私たちはピクロトキシンを人工脳脊髄液に溶かし， $1,3,10,30,100 \mu \mathrm{M}$ という 5 段階の濃度で，スライ

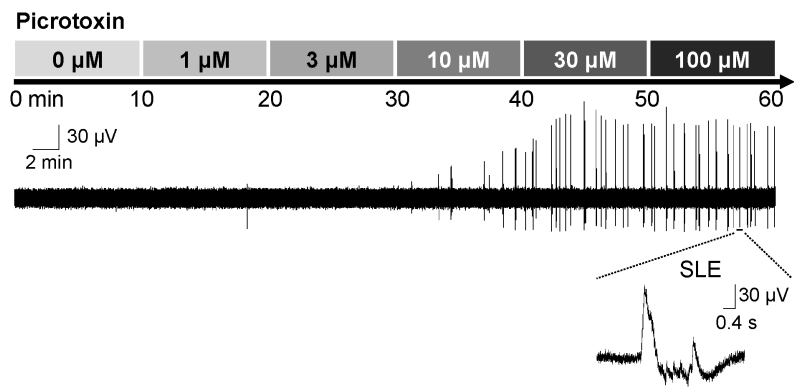

Fig. 1. Picrotoxin Induced SLEs in a Concentration-dependent Manner

Picrotoxin was applied for $10 \mathrm{~min}$ at each concentration. An SLE, enlarged in the bottom inset, comprising an initial burst and subsequent repetitive bursts.

ス上に徐々に濃度を上げて還流し，LFP の変化を 記録した（Fig. 1)。LFP の記録には 64 チャネル多 電極アレイを利用しており，海馬白板という海馬と 皮質をつなぐ脳領域からとつたデー夕を解析に用い た. Figure 1 の LFP トレースが示すように，ピク ロトキシンの濃度が $10 \mu \mathrm{M}$ を超えると, 繰り返し て生じる電位変化が観察されるようになった。これ らの電位変化を拡大すると, 最初の高いピークに小 さい振動が続くという形になっている。このような 神経活動は SLE の特徵に一致し，ピクロトキシン の濃度に依存して発生する。

\section{痸攣誘発作用を持つ薬物は痓攣様発火を引き起こ す}

私たちは，臨床上痤攣誘発性の副作用が報告され た薬物が脳スライスでも SLE を誘発するか，また 逆に, 痤攣の副作用の報告がない薬物がSLE を生 じさせないかを調べた。そのため，作用機序が異な る 13 種類の薬物を選定した。これらの薬物のう ち，ジフェンヒドラミン（ヒスタミン $\mathrm{H} 1$ 受容体拮 抗薬），エノキサシン（DNA ジャイレース阻害 薬)，ストリキニーネ（グリシン受容体阻害薬）及 びテオフィリン（アデノシン受容体拮抗薬）の 4 種 は，臨床上に痙攣を誘発する副作用が報告されてい る。各薬物をヒトにおける血漿中濃度の 0.3 倍， 1 倍, 3 倍, 10 倍及び 30 倍の 5 段階の濃度でスライ ス上に還流し，同時に LFPの変化を記録した (Fig. 2).

記録された各薬物の LFP から見ると, 痤攣誘発 作用が報告された薬物は，濃度依存的にSLE を引 き起こすことがわかつた，これに対して，ほかの薬 物はSLE を誘発しなかった。そのうち，ケタミン 


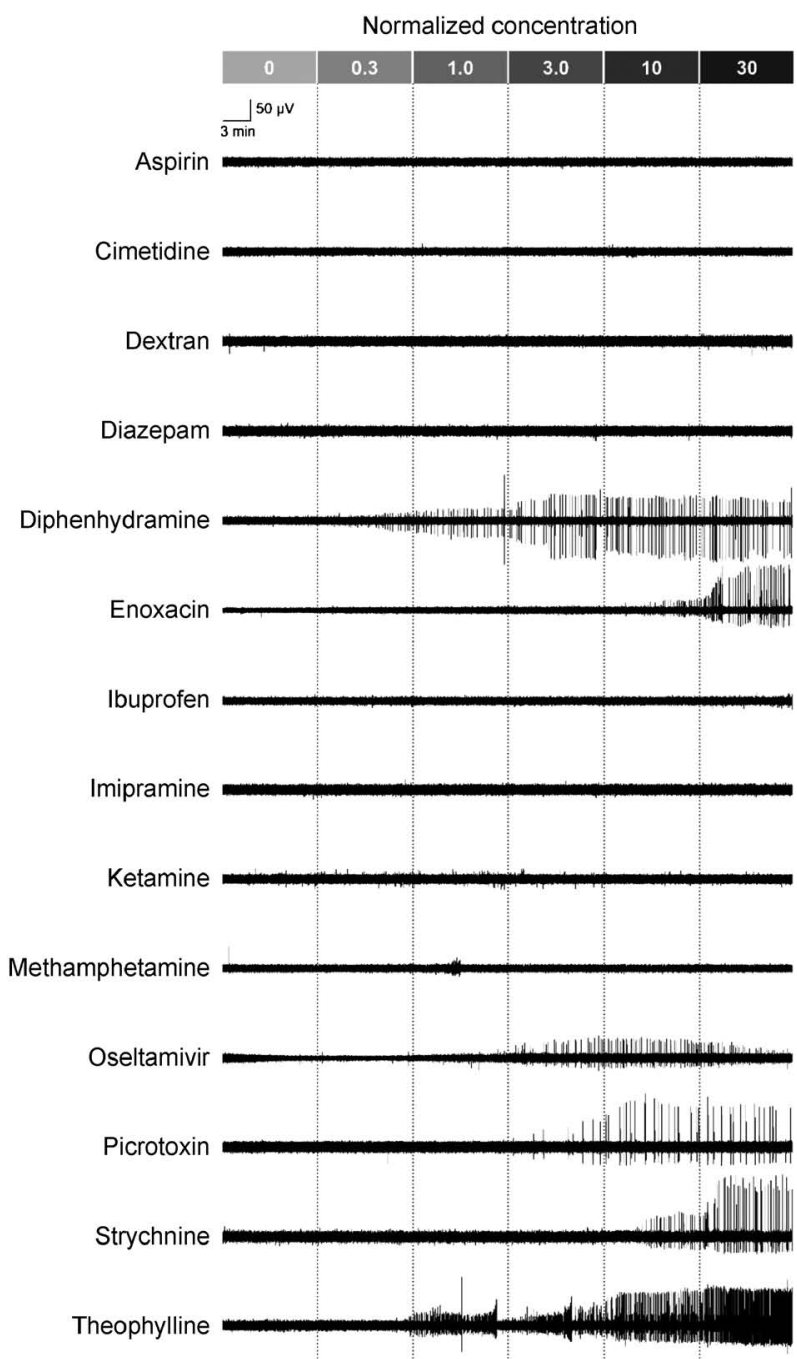

Fig. 2. Example Traces of Alveus LFPs Recorded in the Presence of 14 Different Drugs

The drugs reported to exhibit seizure-inducing side effects, including diphenhydramine, enoxacin, strychnine, and theophylline, indeed induced SLEs.

やメタンフェタミンといつた精神作用を持つ薬物も SLE を誘発しなかつた。つまり，今回の実験系で は，SLEがみられるかどうかを判別することで, 痙攣誘発作用を持つ薬物を見分けることが可能であ る.

\section{LFP の画像化と AI による痤攣誘発作用の判別}

薬物の適用により，痤攣誘発作用を持つ薬物は SLE を引き起こしたが，Fig. 2 のオセルタミビルの ように, SLE 以外の同期的な神経活動が観察され ることもある.SLE と SLE ではない神経活動はヒ トの目で見れば容易に区別できるが，これを数学的 に厳密に定義して検出することが困難である，そこ で，すべての神経活動から SLEのみを選別し，痙 攣誘発作用を持つ薬物を自動的に判別するために,

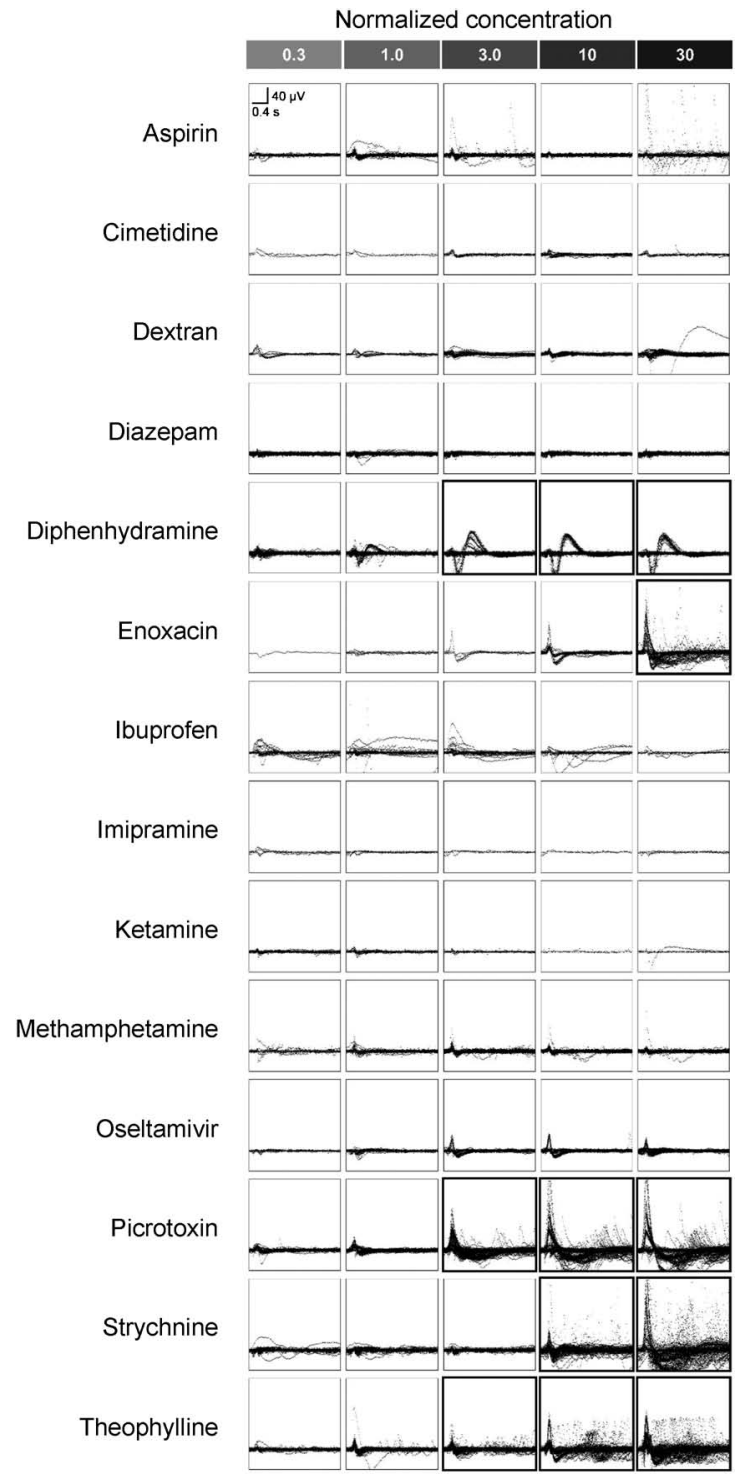

Fig. 3. LFP Images

Large activity events detected from the LFP trace at each drug concentration were aligned to their onsets and superimposed onto a $227 \times 227$ pixel picture ( $n=5$ slices for each drug). Pictures containing at least one SLE are outlined in black.

私たちは AI による画像識別を利用した。

まず，記録された LFP から傾きが $1 \mu \mathrm{V} / \mathrm{ms}$ 以上 の電位変化をすべて検出した．検出された最初の高 いピークに対して，ピークの $-200 \mathrm{~ms}$ から +2070 $\mathrm{ms}$ の時間帯でのトレースを取り出し， -50 から $+177 \mu \mathrm{V}$ の振幅の範囲を, $227 \times 227$ ピクセルの画 像に変換した．つまり，画像上の 1 つのピクセルは $10 \mathrm{~ms} \times 1 \mu \mathrm{V}$ の情報を含んでいる.

次に，各薬物に対して，各濃度で検出されたすべ ての神経活動から得た画像を重ね合わせ，一枚の画 像にした。これにより，ピクロトキシンを含め，全 14 種類の薬物のそれぞれ 5 段階の濃度から 70 枚の 
画像が得られた（Fig. 3)。太枠で示したように, SLE を誘発した 5 種の薬物において, 計 12 枚の画 像が SLE を含んでいる。 一方，メタンフェタミン やオセルタミビルなどの場合，自発的な LFP 活動 が観察されるが, これらの神経活動では最初のピー クに持続的な発火がついておらず，SLEではない ことを画像から確認できる.

私たちはAI を用いて, SLE とSLE ではない神 経活動を正確かつ客観的に判別させようと考えた. そのために，ニューラルネットワークの層構造を模 した，画像識別に特化された AI である Caffe を利 用した. ${ }^{7)}$ Caffe は画像を解析し，ニューラルネット ワークの第六層にて，画像の特徵を抽出して 4096 次元のベクトルデータに変換できる. この多次元の ベクトルデータに対して主成分分析（principal component analysis; PCA) を行い, データ間のば らつきを最大に保存しながら，2 次元に圧縮して第 一及び第二主成分 (PC1, PC2) の空間にプロット した [Fig. 4(A)]。プロットでは，1 つの点が一枚 の LFP 画像に対応している. SLE を含む画像が対 応する点を丸で示すと，これらの点はSLE を含ま ない点と異なる空間象限を占めることが分かった.

さらに, 判別関数の一種であるサポートベクターマ シン (support vector machine; SVM) を用いて，単 一の直線により，これらの点を分離することができ た. すなわち，瘥攣誘発作用を持つすべての薬物は， SVM で引いた境界線の右側に少なくとも 1 つの点 を持つのに対して，病攣誘発作用を持たない薬物は すべての点が境界線の左側にある。つまり，Caffe 及びSVM を用いて，LFP の画像からその特徵を見 い出し，SLE を誘発する薬物を正しく識別するこ とができたことになる.

\section{薬物の病攣誘発作用を高精度で予測できる}

最後に，交差検証を用いて薬物の痙攣誘発作用の 予測を行った．検討した 14 種類の薬物から 1 種を 除き，残りの薬物のデータのみから，上記と同じ方 法で，痤攣誘発作用を持つ薬物を分離する境界線を SVM で引いた。この境界線を用いて，先ほど除か れた薬物が境界線のどちらにプロットされるかを見 ることで，当該薬物は痤攣誘発作用を持つかどうか を予測した．試行の結果，14 種類すべての薬物に ついて，正確な予測が得られた。つまり，予測の Accuracy が 100\%であった.
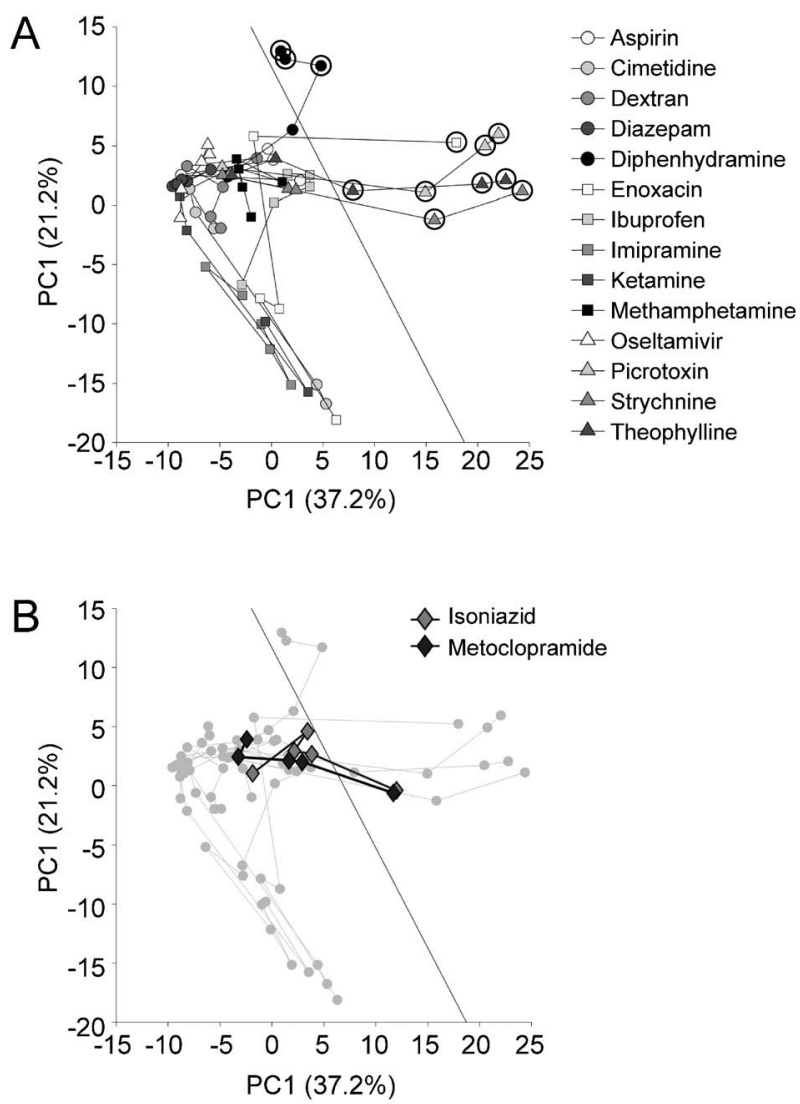

Fig. 4. Detection and Prediction of SLEs Using PCA and SVM

A: Concentration-response curves in the PC space. The 4096-dimensional feature vectors were reduced in dimension using PCA and plotted in the space of the first two PCs, in which each concentration of each drug is indicated in a single point, and different concentrations of the same drug are connected with a line. Black circles indicate doses that induced SLEs (the same as Fig. 3). A boundary (black line) was defined using SVM. All data points containing SLEs were located in the right area, indicating a perfect separation of SLEs in the PC space. B: The boundary determined in (A) correctly predicted the SLE-inducing effects of two new drugs, isoniazid and metoclopramide. In both drugs, parts of data of contained points that were located in the right area of the boundary, indicating their SLE-inducing effects.

この実験系を用いて，全く新しい 2 種類の薬物に ついて追加予測を行った。この 2 種類の薬物はイソ ニアジド（ミコール酸合成阻害薬）とメトクロプラ ミド（ドパミン D2 受容体拮抗薬）であり，どちら も痤攣誘発作用が報告されている。既に実験を行つ た 14 種類の薬物のデータに基づいて，SVM で境界 線を引き，新しい 2 種の薬物を同じプロトコルでプ ロットした. Figure 4(B)のように, どちらの薬物 も境界線の右側までプロットされ，痙攣誘発作用を 持つと判別され，実際の報告と一致している.

\section{展望}

本研究は AI による画像認識を用いて，LFP を画 像化し解析することで，薬物の痤攣誘発作用を予測 
する実験系を構築した。この実験系は薬品開発の前 臨床段階において，動物試験の代わりに，化合物の 痤攣誘発作用を精度よく予測できる手法の 1 つとな ることが期待される。 また，本研究で用いられた画 像認識のモデルは，おそらく多くの一般的な実験 デー夕解析にも応用できると考えている．これから $\mathrm{AI}$ を用いたデー夕解析は, 自動化や高速化のみな らず，人為バイアスのかからない高確度化・高精度 化を実現するものと期待される.

利益相反＼cjkstart開示すべき利益相反はない.

\section{REFERENCES}

1) Litjens G., Kooi T., Bejnordi B. E., Setio A. A. A., Ciompi F., Ghafoorian M., van der Laak J. A. W. M., van Ginneken B., Sánchez C. I., Med. Image Anal., 42, 60-88 (2017).

2) Guan J. S., Lin L. Y., Ji G. L., Lin C. M., Le
T. L., Rudas I. J., Acta Polytech. Hungarica, 13, 39-52 (2016).

3) Shankar A. S., Asokan A., Sivakumar D., Int. J. Latest Eng. Res. Appl., 1 (5) , 68-72 (2016).

4) Tamaki C., Nagayama T., Hashiba M., Fujiyoshi M., Hizue M., Kodaira H., Nishida M., Suzuki K., Takashima Y., Ogino Y., Yasugi D., Yoneta Y., Hisada S., Ohkura T., Nakamura K., J. Txicol. Sci., 38, 581-598 (2013) .

5) Easter A., Sharp T. H., Valentin J. P., Pollard C. E., J. Pharmacol. Toxicol. Meth., 56, 223-233 (2007).

6) Anderson W. W., Lewis D. V., Swartzwelder H. S., Wilson W. A., Brain Res., 398, 215-219 (1986).

7) Jia Y., Shelhamer E., Donahue J., Karayev S., Long J., Girshick R., Guadarrama S., Darrell T., arXiv.org, 1408.5093 (2014). 